\title{
DEVELOPMENT AND FIRST YEAR OPERATION OF EXTENDED WASTEWATER TREATMENT PLANT IN DOBRON
}

\author{
ROZBUDOWA I PIERWSZY ROK PRACY \\ POWIĘKSZONEJ OCZYSZCZALNI ŚCIEKÓW W DOBRONIU
}

\begin{abstract}
The aim of the investigation was characterizing and operation assessment of the wastewater treatment plant in Dobron taking into consideration its flow capacity, before $\left(350 \mathrm{~m}^{3} / \mathrm{d}\right)$ and after development including building of the second technological pipe with the same flow capacity $\left(350 \mathrm{~m}^{3} / \mathrm{d}\right)$, finished in September, 2009. Concise description of the applied wastewater treatment technology and results of investigations concerning flow rates of wastewater within last few years, are presented. Example results of wastewater composition analysis and reached treatment conversion are described. Analysis results of screenings, sand removed from sand traps and stabilized sludge are shown.
\end{abstract}

Keywords: Ecolo-Chief type wastewater treatment plants, phosphorus and nitrogen reduction in wastewater, wastewater treatment

Industrial and municipal wastewater generated during new investments realization as well as development of sewerage systems in villages and towns causes the necessity of building of new wastewater treatment plants and development of existing ones. These plants include conventional mechanical and biological treatment methods (1st and 2nd stage) and guarantee removal of biogenic compounds, ie, nitrogen and phosphorus, in the third stage of treatment [1-5].

Ecolo-Chief type wastewater treatment plants are process lines designed and produced by CHIEF INDUSTRIES, INC. (Nebraska, USA). The system was modernized by Multibranch PPU Sumax, Inc. (Krakow) within the range of biogenic compounds removal and secondary settling tank operation. About 75 wastewater treatment plants using this technology, have been built in Poland [6, 7].

\footnotetext{
${ }^{1}$ Institute of General and Ecological Chemistry, Technical University of Lodz, ul. S. Żeromskiego 116, 90-924 Łódź, Poland, phone +48 4263131 18, fax +48 426313128

${ }^{2}$ Municipality Office of Dobroń, ul. 11 listopada 9, 95-082 Dobroń, Poland

${ }^{*}$ Corresponding author: andrzejzarcz@o2.pl
} 


\section{Results of the treatment}

The wastewater treatment plant is designed for the treatment of municipal wastewater from small and middle-sized settlements and public buildings like schools, hotels, sportrecreation objects, hospitals, etc. This plant can successfully treat wastewater from food industry or other related branches of this industry which produce wastewater with qualitative composition similar to domestic sewage. Object series of types makes the selection of wastewater systems in the range from $28 \div 1290 \mathrm{~m}^{3} / \mathrm{d}$ possible. Table 1 presents the effectiveness of pollutants removal from municipal and industrial wastewater with features similar to domestic sewage, achieved in the Ecolo-Chief systems.

Table 1

Typical effectiveness of pollutants removal from municipal or industrial wastewater with features similar to domestic sewage, in the Ecolo-Chief systems

\begin{tabular}{|c|c|c|c|}
\hline $\begin{array}{c}\text { Pollution indicator in } \\
\text { wastewater }\end{array}$ & Raw wastewater & Treated wastewater & $\begin{array}{c}\begin{array}{c}\text { Pollutants removal } \\
\text { degree }[\%]\end{array} \\
\end{array}$ \\
\hline $\begin{array}{l}\text { Biological Oxygen Demand } \\
\left(\mathrm{BOD}_{5}\right)\left[\mathrm{mg} \mathrm{O}_{2} / \mathrm{dm}^{3}\right]\end{array}$ & 400 & 30.0 & 92.5 \\
\hline $\begin{array}{l}\text { Chemical Oxygen Demand } \\
\text { (COD) }\left[\mathrm{mg} \mathrm{O}_{2} / \mathrm{dm}^{3}\right]\end{array}$ & 750 & 150.0 & 80.0 \\
\hline Total suspended solids $\left[\mathrm{mg} / \mathrm{dm}^{3}\right]$ & 435 & 50.0 & 88.5 \\
\hline Total nitrogen $\left[\mathrm{mg} \mathrm{N} / \mathrm{dm}^{3}\right]$ & 15 & 5.0 & 66.7 \\
\hline Total phosphorus $\left[\mathrm{mg} \mathrm{P}^{2} \mathrm{dm}^{3}\right]$ & 60 & 30.0 & 50.0 \\
\hline
\end{tabular}

Treatment results presented in Table 1, meet that requirements described in attachment No. 2, Table II in the decree of Ministry of the Environment of January 28, 2009 (changing the decree concerning conditions which should be fulfilled during disposal of wastewater into surface water or soil, and concerning substances especially hazardous to the water environment, or other law requirements) [8-10]. Actual removal effectiveness of $\mathrm{BOD}_{5}$ and COD from the wastewater is usually higher than 95 and $90 \%$, respectively.

\section{Experimental}

Biological-mechanical wastewater treatment plant with preliminary treatment of activated sludge in the degree which guarantees protection of Palusznica river (right-bank side stream of Grabia river), was put into operation on January, 1998. This treatment plant has worked smoothly for many years. However, taking into consideration an increasing amount of wastewater, it appeared, that its flow capacity should have been increased.

The aim of the investigation was characterizing and operation assessment of the wastewater treatment plant in Dobron taking into consideration its flow capacity (Q), before $\left(\sim 350 \mathrm{~m}^{3} / \mathrm{d}\right)$ and after development including building of the second technological pipe with the same flow capacity $\left(350 \mathrm{~m}^{3} / \mathrm{d}\right)$, finished on $23^{\text {rd }}$ September, 2009 (Fig. 1).

Concise description of the applied wastewater treatment technology and results of investigations concerning flow rates of wastewater within last few years, are presented below. Wastewater treatment plant in Dobron (Ecolo-Chief type) operates according to the technology of low-loaded activated sludge with aerobic sludge digestion [11-14]. After the development, the wastewater treatment plant includes the following most important devices: * 1 drainage point of supplied wastewater with storage reservoir, 
* 1 wastewater pumping station with basket screen,

* 2 sand traps,

* 2 primary settling tanks,

* 2 oxygen deficiency tanks (anoxic),

* 8 aeration tanks,

* 2 tanks of aerobic sludge digestion,

* 2 secondary settling tanks,

* 2 wastewater wells for measurement of wastewater flow,

* 2 set of rotary blowers.

Technological system for sludge treatment consists of:

* 2 tanks of aerobic sludge digestion,

* 1 sludge pumping station,

* 1 tape press for mechanical removal of sludge (sludge dewatering).

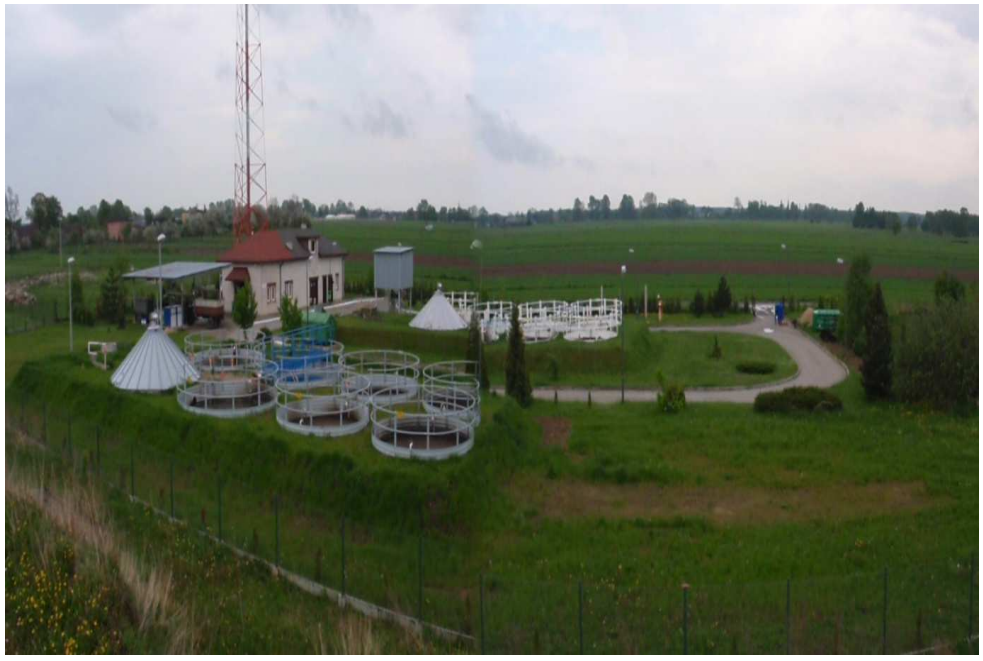

Fig. 1. The view of the developed wastewater treatment plant in Dobron

The Ecolo-Chief type wastewater treatment plants guarantees the possibility of an increase in the efficiency of the basic unit by coupling of separated modules. This is especially important during a development of sludge units and gradual increase in the supplied wastewater which concerned the municipal treatment plant in Dobron. This system operates well also in such objects where seasonal supply of the wastewater, i.e., during summertime, significantly exceeds the average value of other months. The application of the treatment system with periodical recirculation of partial wastewater and sludge causes that all system operates under full loading of pollutants also in the period with lower wastewater supply [7].

\section{Results and discussion}

Annual volumes of wastewater supplied to the wastewater treatment plant in Dobron over the period from 1999 to August, 2010 are presented in the Proceedings of 
ECOpole 2010 [15]. Treatment results of wastewater carried off by sewers and by waste removal transport in the wastewater treatment plant in Dobron over the period of 2009 and January-August, 2010 are shown in Table 2. Consecutive data concerning amounts of pollutants loads and formed technological wastes, are presented in Tables 3 and 4. Example results of wastewater composition, before and after the treatment as well as decrease degree of selected indicators, are shown in Tables 5 and 6 . Analysis of screenings, sand removed from sand traps and stabilized sludge are shown in Tables 7-9.

Table 2

Treatment of wastewater carried off by sewers and by waste removal transport in the wastewater treatment plant in Dobron over the period of 2009 and January-February, 2010 [13, 14]

\begin{tabular}{|c|c|c|c|c|}
\hline \multirow{2}{*}{$\begin{array}{c}\text { Year/Month } \\
2009-2010 \\
\end{array}$} & \multicolumn{2}{|c|}{ Monthly wastewater supply $\left[\mathrm{m}^{3} / \mathrm{month}\right]$} & \multicolumn{2}{|c|}{ Daily wastewater supply $\left[\mathrm{m}^{3} / \mathrm{d}\right]$} \\
\hline & Total & Transported & Total & Transported \\
\hline January & 7111 & 923.8 & 229.4 & 29.8 \\
\hline February & 7155.3 & 940.8 & 255.5 & 33.6 \\
\hline March & 10110.7 & 1036.2 & 326.2 & 33.4 \\
\hline April & 7277.5 & 1217.6 & 242.6 & 40.6 \\
\hline May & 7282.2 & 946.4 & 234.9 & 30.5 \\
\hline June & 7952.2 & 1171.7 & 265.1 & 39.1 \\
\hline July & 6136.9 & 1263.6 & 198.0 & 40.8 \\
\hline August & 7984.6 & 843.8 & 257.6 & 27.2 \\
\hline September & 6903.6 & 875.7 & 230.1 & 29.2 \\
\hline October & 8251 & 1005.9 & 266.2 & 32.5 \\
\hline November & 8158 & 543.5 & 271.9 & 18.1 \\
\hline December & 8981 & 1051.3 & 289.7 & 34.0 \\
\hline 2009 Total & 93304 & 11820.3 & 255.6 (average) & 32.4 (average) \\
\hline January & 8327 & 1134.6 & 268.6 & 36.6 \\
\hline February & 9083 & 1292.7 & 324.4 & 46.2 \\
\hline March & 12525 & 1514.1 & 404.0 & 48.8 \\
\hline April & 10982 & 1756.2 & 366.0 & 58.5 \\
\hline May & 17611 & 801.9 & 568.1 & 25.9 \\
\hline June & 11384 & 1229.3 & 379.5 & 40.9 \\
\hline July & 10844 & 1500 & 349.8 & 48.4 \\
\hline August & 11706 & 1223 & 377.6 & 39.5 \\
\hline 2010 (I-VIII) Total & 92462 & 10451.8 & 379.75 (average) & 43.1 (average) \\
\hline
\end{tabular}

Table 3

Daily average load of pollutants supplied to the wastewater treatment plant in Dobron over the period of 2007-2009 [13, 14]

\begin{tabular}{|c|c|c|}
\hline Indicator name & Concentration $\left[\mathbf{g ~ O}_{\mathbf{2}} \mathbf{~} \mathbf{m}^{\mathbf{3}} \mathbf{~ o r}\left[\mathbf{g} / \mathbf{m}^{\mathbf{3}}\right]\right.$ & Pollutants load [kg/day] \\
\hline BOD $_{5}$ & 247 & 67.9 \\
\hline COD-Cr & 511 & 140.5 \\
\hline TN (total nitrogen) & 86.2 & 23.7 \\
\hline TP (total phosphorus) & 10.4 & 2.9 \\
\hline TSS (total suspended solids) & 222 & 61 \\
\hline
\end{tabular}


Waste types and amounts per month in 2009 and over the period of I-V $2010[13,14]$

\begin{tabular}{|c|c|c|c|}
\hline \multirow{2}{*}{$\begin{array}{c}\text { Year/Month } \\
2009\end{array}$} & \multicolumn{3}{|c|}{ Waste types and amounts [Mg/month] } \\
\hline & Screenings & Sand traps contents & Stabilized sludge \\
\hline January & 0.53 & 0.2 & 4.16 \\
\hline February & 0.43 & 0.3 & 8.44 \\
\hline March & 0.3 & 0.2 & 8.8 \\
\hline April & 0.48 & 0.4 & 7.74 \\
\hline May & 0.43 & 0.3 & 13 \\
\hline June & 0.39 & 0.33 & 9.82 \\
\hline July & 0.52 & 0.3 & 6.44 \\
\hline August & 0.42 & 0.4 & 8.94 \\
\hline September & 0.47 & 0.31 & 7.3 \\
\hline October & 0.44 & 0.5 & 13.2 \\
\hline November & 0.42 & 0.4 & 15.3 \\
\hline December & 0.42 & 0.4 & 11.44 \\
\hline 2009 Total & 5.25 & 4.04 & 114.58 \\
\hline January & 1.08 & 0.6 & 3.24 \\
\hline February & 1.1 & 0.5 & 7.98 \\
\hline March & 1.08 & 0.8 & 6.22 \\
\hline April & 1.05 & 0.8 & 7.92 \\
\hline May & 1.0 & 0.6 & 8.22 \\
\hline I-V 2010 Total & 5.31 & 3.3 & 33.58 \\
\hline
\end{tabular}

Table 5

Examples of composition analyses in raw and treated wastewater over the period of 2008-2010 [13, 14]

\begin{tabular}{|c|c|c|c|c|}
\hline \multirow{2}{*}{$\begin{array}{c}\text { Date of } \\
\text { wastewater } \\
\text { sampling } \\
\end{array}$} & \multicolumn{4}{|c|}{ Contamination indicator in raw and treated wastewater } \\
\hline & pH & BOD $_{5}$ & COD-Cr & $\begin{array}{c}\text { Total suspended } \\
\text { solids } \\
\end{array}$ \\
\hline & - & {$\left[\mathrm{mg} \mathrm{O}_{2} / \mathbf{d m}^{3}\right]$} & {$\left[\mathrm{mg} \mathrm{O}_{2} / \mathbf{d m}^{3}\right]$} & {$\left[\mathrm{mg} / \mathrm{dm}^{3}\right]$} \\
\hline 16.05.2008 & 7.4/7.4 & $682 / 10$ & $1109 / 56.4$ & $241 / 20$ \\
\hline 21.11.2008 & $7.4 / 7.1$ & $319 / 2.7$ & $550 / 17$ & $133 / 14$ \\
\hline 05.02 .2009 & $7.8 / 7.1 \div 7.3$ & $485 / 8.1$ & $804 / 52$ & $34 / 11$ \\
\hline 14.05.2009 & $7.6 / 7.2 \div 7.3$ & $739 / 18.0$ & $1246 / 105$ & $763 / 18$ \\
\hline 13.08.2009 & $8.0 / 7.8 \div 8.4$ & $695 / 9.0$ & $1171 / 45$ & $120 / 13$ \\
\hline 03.11 .2009 & $-/ 7.4 \div 7.6$ & $-/ 7.03$ & $-/ 40$ & $-/ 6.0$ \\
\hline 16.02 .2010 & $7.5 / 7.3$ & $610 / 15.9$ & $1022 / 72$ & $230 / 6.0$ \\
\hline 10.06 .2010 & $6.6 / 7.1$ & $466 / 11.6$ & $826 / 57$ & $388 / 15$ \\
\hline 30.08 .2010 & $7.6 / 7.3$ & $366 / 13.8$ & $633 / 64$ & $349 / 5.0$ \\
\hline
\end{tabular}


Example decrease efficiencies of selected pollutants indicators in the raw and treated wastewater over the period of 2008-2010

\begin{tabular}{|c|c|c|c|}
\hline \multirow{2}{*}{$\begin{array}{c}\text { Date } \\
\text { of wastewater } \\
\text { sampling }\end{array}$} & \multicolumn{2}{|c|}{ Contamination indicator in raw and treated wastewater } \\
\cline { 2 - 4 } & Conversion BOD $_{\mathbf{5}}$ & $\begin{array}{c}\text { Conversion } \\
\text { COD Cr }\end{array}$ & $\begin{array}{c}\text { Conversion } \\
\text { of total suspended solids }\end{array}$ \\
\hline 16.05 .2008 & 98.5 & {$[\%]$} & 91.7 \\
\hline 21.11 .2008 & 99.2 & 94.9 & 89.5 \\
\hline 05.02 .2009 & 98.3 & 96.9 & 91.8 \\
\hline 14.05 .2009 & 97.6 & 93.5 & 95.1 \\
\hline 13.08 .2009 & 98.7 & 91.6 & 89.2 \\
\hline 03.11 .2009 & - & 96.2 & - \\
\hline 16.02 .2010 & 97.4 & - & 97.4 \\
\hline 10.06 .2010 & 97.5 & 93.0 & 96.1 \\
\hline 30.08 .2010 & 96.2 & 93.1 & 98.6 \\
\hline
\end{tabular}

Analysis results of screenings sampled on April 22, 2010 [13, 14]

\begin{tabular}{|c|c|}
\hline Determination type & Analysis results [mg/kg dry matter] \\
\hline Chlorides & 82 \\
\hline Fluorides & 9 \\
\hline Sulphates & 82 \\
\hline DOC (dissolved organic carbon) & 198 \\
\hline TDS (total dissolved solids) & 8225 \\
\hline Zinc & 3.9 \\
\hline Copper & 0.41 \\
\hline General chromium & 0.34 \\
\hline Nickel & 0.27 \\
\hline Lead & 0.52 \\
\hline Cadmium & 0.06 \\
\hline Mercury & 0.0015 \\
\hline Molybdenum & 0.08 \\
\hline Antimony & 0.003 \\
\hline Selenium & 0.04 \\
\hline Arsenic & 0.04 \\
\hline Barium & 1.8 \\
\hline
\end{tabular}


Constitution analysis results of sand sampled from the sand trap on April 22, 2010 [13, 14]

\begin{tabular}{|c|c|}
\hline Determination type & $\begin{array}{c}\text { Analysis results } \\
\text { [mg/kg dry matter] }\end{array}$ \\
\hline Chlorides & 51 \\
\hline Fluorides & 0.6 \\
\hline Sulphates & 51 \\
\hline DOC (dissolved organic carbon) & 112 \\
\hline TDS (total dissolved solids) & 1124 \\
\hline Zinc & 2.7 \\
\hline Copper & 0.29 \\
\hline General chromium & 0.21 \\
\hline Nickel & 0.19 \\
\hline Lead & 0.46 \\
\hline Cadmium & 0.002 \\
\hline Mercury & 0.0009 \\
\hline Molybdenum & 0.06 \\
\hline Antimony & 0.002 \\
\hline Selenium & 0,03 \\
\hline Arsenic & 0.02 \\
\hline Barium & 2.4 \\
\hline
\end{tabular}

Example results of wastewater sludge analysis $[13,14]$

\begin{tabular}{|c|c|c|c|}
\hline Determination type & $\begin{array}{c}\text { Determination } \\
\text { unit }\end{array}$ & $\begin{array}{c}\text { Analysis of sludge sampled } \\
\text { on February 6, 2009 }\end{array}$ & $\begin{array}{c}\text { Analysis of sludge sampled } \\
\text { on February 16, 2010 }\end{array}$ \\
\hline $\mathrm{pH}$ & - & 7.54 & 7.2 \\
\hline Dry matter content & {$[\%]$} & 26 & 15.2 \\
\hline Organic substances content & {$[\%]$} & 54 & 68.3 \\
\hline Total Kjeldahl nitrogen & {$[\%]$} & 1.66 & 6.91 \\
\hline Ammonia nitrogen & {$[\%]$} & 2.6 & 0.46 \\
\hline Lead & {$[\mathrm{mg} / \mathrm{kg}$ d.m. $*]$} & 16.8 & $<12$ \\
\hline Nickel & {$[\mathrm{mg} / \mathrm{kg} \mathrm{d.m.]}$} & 4.7 & $<8$ \\
\hline Zinc & {$[\mathrm{mg} / \mathrm{kg}$ d.m.] } & 0.2 & $<2$ \\
\hline Copper & {$[\mathrm{mg} / \mathrm{kg}$ d.m. $]$} & 0.9 & $<8$ \\
\hline Cadmium & {$[\mathrm{mg} / \mathrm{kg}$ d.m. $]$} & 0.003 & $<8$ \\
\hline Chromium & {$[\mathrm{mg} / \mathrm{kg}$ d.m.] } & n.d.** & 0.003 \\
\hline Mercury & {$[\mathrm{mg} / \mathrm{kg}$ d.m. $]$} & n.d. & n.d. \\
\hline Salmonella type bacteria & - & n.d. & n.d. \\
\hline Parasite ova & - & n.d. & \\
\hline
\end{tabular}

* d.m. - dry matter

**n.d. - not detected 
Increasing amount of wastewater carried off by sewerage or supplied by waste removal transport as well as wastewater load forced making a decision concerning the development of the wastewater treatment plant in Dobron (Tables 2 and 3). Before the development, this plant was gradually approaching to the limit of the maximum loading $\left(350 \mathrm{~m}^{3} / \mathrm{d}\right)$, especially in periods of increased supply of the wastewater. Beginning from September, 2009, the plant can treat the wastewater in the amount of $700 \mathrm{~m}^{3} / \mathrm{d}$. The increased flow capacity guarantees achievement of satisfactory values of the operating indicators over a dozen years. The composition of the wastewater disposed to Palusznica river fulfills law requirements [8-10] and does not raise any doubts. This plant is not hazardous for inhabitants taking into consideration odours, due to the applied treatment technology and favourable location. This is proved by lack of inhabitants' complaints about the plant operation. Up to now, no hazard of the plant to the quality of underground and surface water was found. Solid wastes (screenings, sand from sand traps and stabilized sludge) are carried outside the plant to another firm in order to utilize them.

\section{Conclusions}

The increased flow capacity of the plant to $700 \mathrm{~m}^{3} / \mathrm{d}$ guarantees the achievement of satisfactory operation indicators. The plant operation is not odour hazardous for inhabitants due to its proper location to other buildings (lack of inhabitants' complaints). No hazard to the quality of surface and underground waters resulting from the treatment plant operation was found so far. Analysis results of screenings, sand removed from sand traps, and stabilized sludge are shown. Solid wastes formed during the technological process of the wastewater treatment (screenings, sand from sand traps and stabilized sludge) are disposed outside the plant in order to utilized them.

\section{Acknowledgement}

Authors are grateful to the Municipality Office in Dobron for their consent to use the analytical data concerning the municipal wastewater treatment plant.

\section{References}

[1] Poradnik eksploatatora oczyszczalni ścieków. Dymaczewski Z, Sozański M, editors. Poznań: Polskie Zrzeszenie Inżynierów i Techników Sanitarnych, Oddział w Poznaniu; 1997. ISBN: 83-902173-5-X.

[2] Błażejewski R. Kanalizacja wsi. Poznań: Polskie Zrzeszenie Inżynierów i Techników Sanitarnych, Oddział Wielkopolski; 2003. ISBN: 8391425231.

[3] Łomotowski J, Szpindor A. Nowoczesne systemy oczyszczania ścieków. Warszawa: Arkady; 2002. ISBN: 832134139X.

[4] Sabliy L, Kuzminskiy Y, Gvozdyak P, Łagód G. Anaerobic treatment of wastewater of milk plants. Proc ECOpole. 2009;3(2):373-378.

[5] De-Bashan LE, Bashan Y. Recent advances in removing phosphorus from wastewater and its future use as fertilizer (1997-2003). Water Res. 2004;38(19):4222-4246. DOI: 10.1016/j.watres.2004.07.014.

[6] http://www.chiefind.com/products/wastewater-treatment

[7] http://www.sumax.com.pl/index

[8] Rozporządzenie Ministra Środowiska z dnia 24 lipca 2006 r. w sprawie warunków, jakie należy spełnić przy wprowadzaniu ścieków do wód lub ziemi, oraz w sprawie substancji szczególnie szkodliwych dla środowiska wodnego. DzU 2006, Nr 137, poz. 984.

[9] Rozporządzenie Ministra Budownictwa z dnia 14 lipca 2006 r. w sprawie sposobu realizacji obowiązków dostawców ścieków przemysłowych oraz warunków wprowadzania ścieków do urządzeń kanalizacyjnych. DzU 2006, Nr 136, poz. 964. 
[10] Rozporządzenie Ministra Środowiska z dnia 28 stycznia 2009 r. zmieniające rozporządzenie w sprawie warunków, jakie należy spełnić przy wprowadzeniu ścieków do wód lub do ziemi, oraz w sprawie substancji szczególnie szkodliwych dla środowiska wodnego. DzU 2009, Nr 27, poz. 169.

[11] Kabaciński Z, Szczepaniak E. Gminny Program Ochrony Środowiska dla Gminy Dobroń na lata 2008-2012. Wójt Gminy Dobroń; 2008.

[12] http://www.dobron.ug.gov.pl

[13] Witczak P. Rozbudowa i pierwsze miesiące pracy gminnej oczyszczalni ścieków w Dobroniu [Praca dyplomowa magisterska]. Łódź: IChOiE, Politechnika Łódzka; 2010.

[14] Rezultaty pomiarów ilości przyjmowanych ścieków, a także wyniki okresowych analiz składu ścieków i odpadów eksploatacyjnych Oczyszczalni Ścieków w Dobroniu (unpublished).

[15] Żarczyński A, Witczak P. Development and activation of the second technological pipe in the wastewater treatment of plant in Dobron. Proc ECOpole. 2011;5(1):139-143.

\title{
ROZBUDOWA I PIERWSZY ROK PRACY POWIĘKSZONEJ OCZYSZCZALNI ŚCIEKÓW W DOBRONIU
}

\author{
${ }^{1}$ Instytut Chemii Ogólnej i Ekologicznej, Politechnika Łódzka \\ ${ }^{2}$ Urząd Gminy w Dobroniu
}

\begin{abstract}
Abstrakt: Celem pracy była charakterystyka i ocena funkcjonowania oczyszczalni w gminie Dobroń (biorąc pod uwagę jej przepustowość) przed rozbudową $\left(\sim 350 \mathrm{~m}^{3} / \mathrm{d}\right)$ i po rozbudowie o drugą nitkę technologiczną (także $350 \mathrm{~m}^{3} / \mathrm{d}$ ), zakończoną we wrześniu 2009 r. Oprócz zwięzłego opisu realizowanej technologii oczyszczalnia ścieków, przedstawiono wyniki badań natężenia ich przepływu z ostatnich kilku lat. Ukazano także przykładowe rezultaty analiz składu ścieków surowych oraz uzyskane stopnie ich oczyszczenia. Przedstawiono rezultaty analizy składu skratek, piasku usuwanego z piaskowników i ustabilizowanego osadu ściekowego.
\end{abstract}

Słowa kluczowe: oczyszczalnie typu EcoloChief, redukcja fosforu i azotu w ściekach, oczyszczanie ścieków 